\title{
Analisis Kepuasan Mahasiswa Terhadap Pelayanan Akademik Prodi Sastra Inggris Universitas Dharma Andalas Padang
}

\section{(Student Satisfaction Analysis of English Literature Department Academic Services at Dharma Andalas University Padang)}

\author{
Irsyad Shabri' ${ }^{1)}$, Rahma Yanti ${ }^{2)}$ \\ ${ }^{1}$ Prodi Sastra Inggris, Universitas Dharma Andalas Padang \\ email: irdhie_disya@yahoo.com \\ ${ }^{21}$ Prodi Sastra Inggris, Universitas Dharma Andalas Padang \\ email: rahma.yanti83@gmail.com
}

\begin{abstract}
Abstrak: Competition in the world of tertiary education is currently so rapidly. Both for public and private colleges. The government also began to apply certain standards to improve the university competence. English Literature Department at Dharma Andalas University, one of the private universities in Padang, is aware of this competition. One of the ways to get victory in inter-university competitions is to improve the service facilities that provided the students to gain satisfaction in addition for increasing other things. Research conducted on the relationship between service facilities provided by the English Literature Department and student satisfaction turned out that only a small proportion considered the existence of a relationship. This study uses a quantitative verification approach using descriptive and clear survey methods. Regression analysis is used to analyze data which referring to SPSS version 16. The result of this research is $34.48 \%$ of participants assume that reliability is the highest mean value, so it can be concluded that the aspect of reliability is the most influential aspect in the formation of the satisfaction felt by students for academic services provided by the English Literature Department at the Dharma University of Andalas Padang
\end{abstract}

\section{Keywords: College, Service Academic and Student Satisfaction}

\section{PENDAHULUAN}

\subsection{Latar Belakang}

Perguruan tinggi dituntut agar dapat bersaing dengan perguruan tinggi lainnya. Persaingan yang kompetitif antar perguruan tinggi sangat menuntut lembaga pendidikan senantiasa memperhatikan mutu pendidikan dan kelembagaan sehingga mampu serta unggul dalam persaingan tersebut. Perguruan tinggi haruslah mampu merencanakan dan melakukan langkahlangkah antisipasi guna menghadapi banyak persaingan yang tentunya semakin kompetitif. Selain itu juga bertanggung jawab untuk menggali dan meningkatkan segala aspek pelayanan yang dimiliki. Oleh sebab itu, perguruan tinggi perlu melakukan pengkajian terhadap aspekaspek yang dibutuhkan dalam meningkatkan pelayanan tersebut.
Peningkatan kualitas layanan tidak hanya sekadar dilakukan oleh perguruan tinggi saja, tetapi termasuk kepada unit-unit kerja dalam perguruan tinggi pun harus ikut berpartisipasi. Karena keberhasilan perguruan tinggi tidak terlepas dari keberhasilan unit-unit kerjanya. Sama halnya pengukuran mutu pada suatu program studi (prodi). Keberhasilan prodi sebagai unit kerja dalam perguruan tinggi tentunya dipengaruhi oleh mutu pelayanan yang diberikan, dimana pelayanan yang bermutu dapat diidentifikasi melalui kepuasan pelanggan, dalam hal ini adalah mahasiswa. Hal ini sesuai dengan pendapat Cravens (Handayani, dkk., 2003) menyatakan bahwa, "Untuk mencapai tingkat kepuasan yang tinggi, diperlukan adanya pemahaman tentang apa yang diinginkan oleh konsumen, 
dengan mengembangkan komitmen setiap orang yang ada dalam lembaga untuk memenuhi kebutuhan konsumen". Senada dengan pendapat tersebut disebutkan dalam teori consumer behavior menyatakan bahwa kepuasan pelanggan adalah perspektif pengalaman konsumen setelah mengkonsumsi atau menggunakan produk atau jasa (Oliver,1993: 65).

Prodi Sastra Inggris merupakan salah satu unit kerja yang berada di bawah Universitas Dharma Andalas Padang. Sebagai bagian dari unit kerja, Prodi Sastra Inggris harus menerapkan konsep mengutamakan kepuasan mahasiswa sebagai pelanggan dengan memberikan pelayanan terbaik. Beberapa bidang pelayanan yang harus dikembangkan secara berkelanjutan oleh prodi seperti meliputi: kurikulum jurusan, proses pembelajaran, sumber daya manusia (dosen, pegawai, teknisi), mahasiswa, sarana dan prasarana, suasana akademik, penelitian serta publikasi, pengabdian kepada masyarakat, manajemen lembaga, sistem informasi, dan kerjasama dengan perguruan tinggi baik di tingkat wilayah maupun nasional.

Bertambahnya jumlah mahasiswa akan menimbulkan banyak dinamika dalam pengelolaan Program Studi ini. Berbagai persoalan akan semakin kompleks. Prodi Sastra Inggris saat ini tidak memiliki tenaga administrasi yang membantu Ketua Prodi dan Sekretaris Prodi dalam memberikan layanan kepada mahasiswa. Selain itu disaat yang bersamaan, mahasiswa juga mengharapkan dapat diberikan layanan terbaik dalam berbagai urusan mereka dengan Prodi. Tidak jarang karena urusan administrasi Prodi yang dilaksanakan oleh Ketua dan Sekretaris Prodi membuat mahasiswa yang ingin mendapat layanan Prodi harus menunggu. Ini akan berdampak kepada kepuasan mahasiswa dalam mendapatkan pelayanan akademik pada tingkat Prodi.

Berdasarkan latar belakang di atas, yang menjadi rumusan masalah umum dalam penelitian ini adalah bagaimana bentuk kepuasan mahasiswa terhadap layanan akademik di Prodi Sastra Inggris Universitas Dharma Andalas Padang.

\section{TINJAUAN PUSTAKA}

\subsection{Kepuasan Mahasiswa}

Wilkie (dalam Tjiptono, 1997) mengungkapkan bahwa kepuasan pelanggan adalah suatu tanggapan emosional pada evaluasi terhadap pengalaman konsumsi suatu produk atau jasa, sehingga dapat dikatakan bahwa kepuasan merupakan tingkat perasaan konsumen yang diperoleh setelah konsumen melakukan/ menikmati sesuatu. Menurut Tjiptono (1997: 24) kepuasan atau ketidakpuasan pelanggan merupakan respon pelanggan terhadap evolusi ketidaksesuaian (disconfirmation) yang dirasakan antara harapan sebelumnya dan kinerja aktual produk yang dirasakan

\subsection{Faktor-faktor yang Mempengaruhi Kepuasan Mahasiswa}

Parasuraman

mengungkapkan 5 faktor penentu mutu jasa pelayanan, yaitu:

a. Keandalan (Reliability) yaitu kemampuan

dosen/karyawan/pengelola untuk memberikan jasa sesuai dengan yang dijanjikan, terpercaya, akurat dan konsisten.

b. Daya Tanggap (Responsiveness) yaitu kemauan dari dosen/karyawan/pengelola dan pemilik lembaga untuk membantu pelanggan dan memberikan jasa dengan cepat dan bermakna serta kesediaan mendengar dan mengatasi keluhan yang diajukan konsumen.

c. Kepastian (Assurance) yaitu berupa kemampuan dosen/karyawan/pengelola untuk menimbulkan keyakinan dan kepercayaan terhadap janji yang 
telah dikemukakan kepada konsumen.

d. Empati (Empathy) yaitu kesediaan dosen/karyawan/pengelola untuk lebih peduli memberikan perhatian secara pribadi kepada pelanggan.

e. Berwujud (Tangible) yaitu berupa penampilan fasilitas fisik, peralatan, dan berbagai materi komunikasi.

\section{METODE PENELITIAN}

\section{1 Jenis Penelitian}

Jenis penelitian ini merupakan penelitian deskriptif kuantitatif yang bertujuan untuk menggambarkan tingkat kepuasan akademik serta faktor yang mempengaruhi kepuasan akademik mahasiswa di Prodi Sastra Inggris. Data didapatkan melalui pendekatan kuantitatif dengan metode survey dengan menyebarkan kuesioner kepada mahasiswa Prodi Sastra Inggris Universitas Dharma Andalas Padang.

\section{2 Variabel dan Desain Penelitian}

Variabel pada penelitian ini adalah kepuasan akademik mahasiswa di Prodi Sastra Inggris Universitas Dharma Andalas Padang. Desain pada penelitian ini menggunakan pendekatan kuantitatif. Metode kuantitatif dilakukan untuk mengetahui tingkat kepuasan mahasiswa dan faktor-faktor yang mempengaruhi kepuasan mahasiswa tersebut.

\section{3 Instrumen penelitian}

Instrumen dalam penelitian studi penelusuran ini menggunakan kuesioner. Untuk menyusun kuesioner yang baik, peneliti perlu mempelajari data mahasiswa yang ada di Prodi Sastra Inggris Universitas Dharma Andalas Padang. Aitem-aitem pertanyaan dalam instrumen penelitian ini disusun berdasarkan aspek-aspek yang mempengaruhi kepuasan akademik mahasiswa.

\section{4 Teknik pengumpulan data}

Metode pengumpulan data pada penelitian ini didapatkan dari teknik pengumpulan data melalui penyebaran kuesioner. Kuisioner ini nantinya akan dibagikan kepada mahasiswa di Prodi Sastra Inggris Universitas Dharma Andalas Padang.

\section{5 Lokasi Penelitian}

Penelitian ini mengambil lokasi di Universitas Dharma Andalas Padang. Alasan mengambil tempat penelitian ini adalah karena peneliti merupakan dosen kampus tersebut sehingga mempermudah untuk melakukan pengamatan dan wawancara. Waktu penelitian dilaksanakan selama enam bulan mulai bulan Juli 2019 sampai Desember 2019.

\section{6 Metode dan Teknik Analisis Data}

Data yang didapatkan dari pengisian kuisioner akan diolah dengan mengunakan statistik deskriptif. Hasil pengolahan data statistik deskriptif akan menggunakan program SPSS versi 16.

\section{ANALISA DATA DAN HASIL}

Penelitian dilakukan dengan cara membagikan kuesioner kepada 28 orang mahasiswa Prodi Sastra Inggris Universitas Dharma Andalas Padang. Kuesioner penelitian ini dibagi menjadi 6 aspek yakni tangibles, reliability, responsiveness, assurance, empathy dan information system. Jumlah aitem secara keseluruhan adalah sebayak 41 aitem. Skala respon yang digunakan dalam kuesioner peneliti menggunakan skala Likert. Skor total dari pengisian aitem merupakan skor kepuasan terhadap layanan akademik.

Untuk melihat tinggi rendahnya tingkat kepuasan mahasiswa terhadap layanan akademik Prodi Sastra Inggris Universitas Dharma Andalas Padang, 
dikategorisasikan dari nilai dan dari pengisian kuesioner yang sebelumnya telah selesai dilakukan. Kategori tersebut dibagi menjadi dua yaitu kepuasan yang tinggi dan kepuasan yang rendah. Kategori tersebut dilakukan dengan cara membagi dua nilai kepuasan mahasiwa. Nilai mean dijadikan titik pusat dalam proses pembagian tersebut. Hal ini berarti, apabila nilai mahasiswa berada di bawah mean maka diartikan kategori rendah sedangkan apabila nilai berada di atas mean akan dikategorikan menjadi tinggi. Hasil data dapat dilihat dari tabel 1.

Hasil Kategorisasi Kepuasan Mahasiswa

\begin{tabular}{lll}
\hline Kategori & Frekuensi & Persen \\
\hline Tinggi & 5 & 18.5 \\
\hline Sedang & 18 & 66.6 \\
\hline Rendah & 4 & 14.8 \\
\hline Total & 27 & 100 \\
\hline
\end{tabular}

Dari hasil kategorisasi kepuasan mahasiswa pada tabel 1 dapat dilihat bahwa sebanyak 5 orang mahasiswa atau 18.5 persen memiliki tingkat kepuasan yang tinggi terhadap layanan akademik Prodi Sastra Inggris Universitas Dharma Andalas Padang. Sebanyak 18 orang mahasiswa atau 66.6 persen memiliki tingkat kepuasan yang sedang terhadap layanan akademik. Sebanyak 4 orang atau 14.8 persen memliki tingkat kepuasan yang rendah terhadap layanan akademik. Kemudian didapatkan 1 kuisioner yang error karena ada beberapa data yang tidak diisi sehingga data tidak dapat digunakan. Maka dapat diambil kesimpulan bahwa kepuasan akademik mahasiswa Prodi Sastra Inggris Universitas Dharma Andalas Padang berada pada kategori sedang.

Kemudian, Dari hasil tersebut maka dapat dikatakan bahwa aspek reliability yang paling tinggi nilai meannya, sehingga dapat disimpulkan bahwa aspek reliability merupakan aspek yang paling mempengaruhi dalam pembentukan kepuasan yang dirasakan oleh mahasiswa atas pelayanan akademik yang diberikan oleh Prodi Sastra Inggris Universitas Dharma Andalas Padang. Aspek keandalan (Reliability) yaitu kemampuan dosen/karyawan/pengelola untuk memberikan jasa sesuai dengan yang dijanjikan, terpercaya, akurat dan konsisten. Sebagaimana bisa dilihat pada tabel 2.

Tabel 2. Nilai Mean Aspek Kepuasan Akademik

\begin{tabular}{lll}
\cline { 2 - 3 } No & Aspek Kepuasan Akademik & Mean \\
\cline { 2 - 3 } 1. & Tangibles & 27.59 \\
\cline { 2 - 3 } 2. & Reliability & 34.48 \\
\cline { 2 - 3 } 3. & Responsive & 23.04 \\
\cline { 2 - 3 } 4. & Assurance & 24.01 \\
\cline { 2 - 3 } 5. & Empathy & 23.74
\end{tabular}

\section{KESIMPULAN DAN SARAN \\ 6.1 Kesimpulan}

Penelitian analisis analisis kepuasan mahasiswa terhadap pelayanan akademik Program Studi Sastra Inggris Universitas Dharma Andalas ini memfokuskan pada gambaran tingkat kepuasan akademik mahasiswa dan faktor apa yang paling dominan mempengaruhi kepuasan mahasiswa dilihat dari aspek yang membangun kepuasan tersebut. Oleh sebab itu berdasarkan kegiatan penelitian yang dilaksanakan oleh Tim yang beranggotakan 2 orang dari Program Studi Sastra Inggris Universitas Dharma Andalas, maka dapat ditarik beberapa kesimpulan sebagai berikut :

1. Mahasiswa Sastra Inggris memiliki kepuasan yang sedang terhadap pelayanan akademik Program Studi Sastra Inggris Universitas Dharma Andalas

2. Aspek Reliability merupakan aspek yang paling dominan mempengaruhi kepuasan mahasiswa Program Studi 
Sastra Inggris Universitas Dharma Andalas

\subsection{Saran}

Berdasarkan hasil penelitian yang dilakukan, maka perlu direkomendasikan beberapa hal :

1. Perlu dilakukan penelitian lanjutan untuk lebih mendalami faktorfaktor yang mempengaruhi kepuasan mahasiswa terhadap layanan akademik di Program Studi Sastra Inggris Universitas Dharma Andalas.

2. Perlu kiranya dilakukan pengembangan prodi, dikarenakan kepuasan akademik mahasiswa yang masih sedang.

\section{DAFTAR PUSTAKA}

Cresswell, J, W. 2014. Research Design: Pendekatan Kualitatif, Kuantitatif, dan Mixed. Yogyakarta: Pustaka Pelajar.

Handayani, R, Yermias T. K., dan Ratminto. 2003. "Analisis Kepuasan Pemakai terhadap Pelayanan Perpustakaan Nasional Provinsi Daerah Istimewa Yogyakarta”. Sosiosains, Volume 17 Nomor 2, April 2003. Yogyakarta : Pasca Sarjana Fisipol UGM.

Harun, H. 2006. Analisis Faktor-Faktor Yang Mempengaruhi Kepuasan Pelanggan Untuk Meningkatkan Loyalitas Pelanggan Produk Telkom Flexi (Studi Kasus PT. Telekomunikasi Indonesia Kota Semarang). Tesis. Program Studi Magister Manajemen. Universitas Diponegoro Semarang

Kotler, P. 1997. Manajemen Pemasaran: Analisis, Perencanaan, Implementasi dan pengendalian (Edisi kedelapan, terjemahan Arcella
Ariwati Hermawan). Jakarta: Salemba Empat

Mowen, J. C. 1995. Consumer Behavior, Eleventh Edition. Illinois: Richard D. Irwin Inc.

Oliver, R. L. 1993. Satisfaction : A Behavioral Perspective on the Consumer. Mc Graw Hill : International Edition.

Parasuraman, V A, Zeithamil, and Leonard L. Berry, "SERVQUAL: A,MultipleItem Scale for Measuring Consumer Perceptions of Service Quality". Journal of Retailing Volume 64 Number 1 Spring 1988, pp.12-40

Sadat, A. M. 2000. Analisis Hubungan Kinerja Jasa Perguruan Tinggi terhadap Kepuasan Mahasiswa :Studi Kasus Universitas Indonesia. Jakarta : Program Pasca Sarjana Ilmu Ekonomi dan Manajemen Universitas Indonesia.

Sugito, H. 2005. Mengukur Kepuasan Pelanggan. (On-line). www.eprints.qut. edu/achieve/0003941/01/3491 /pdf. Diakses 14 November 2018.

Suryana, D, dkk. 2014. Kepuasan Mahasiswa Terhadap Pelayanan Akademik Di Jurusan Pendidikan Guru Pendidikan Anak Usia Dini Fakultas Ilmu Pendidikan Universitas Negeri Padang. Padang : Fakultas Ilmu Pendidikan Universitas Negeri Padang

Tjiptono, F. 1997. Strategy Pemasaran. Yogyakarta:Andi offset

Widhianto, E. 2007. Analisis FaktorFaktor Yang Mempengaruhi Kepuasan Pelanggan PO Purwo Widodo Di Sidoarjo, Wonogiri. Skripsi. Jurusan Manajemen. Fakultas 
Ekonomi Universitas

Muhammadiyah Surakarta

Windhyastiti, I dan Khouroh, U. 2003. Mutu Pelayanan Jasa

Pendidikan di Fakultas

Ekonomi Universitas Merdeka

Malang (Pendekatan Serqual).
Jurnal Penelitian Ilmu-ilmu Sosial. Volume XV, Nomor 2. Lembaga Penelitian Universitas Merdeka. Malang. https://luk.staff.ugm.ac.id/atur/RenstraKe mdikbud2010-2014.pdf, diakses pada tanggal 18Juni 2019 pukul 23.45 WIB 